\title{
Effects of high-fat diets on fetal growth in rodents: a systematic review
}

\author{
Julian K. Christians ${ }^{*} \mathbb{D}$, Kendra I. Lennie, Lisa K. Wild and Raajan Garcha
}

\begin{abstract}
Background: Maternal nutrition during pregnancy has life-long consequences for offspring. However, the effects of maternal overnutrition and/ or obesity on fetal growth remain poorly understood, e.g., it is not clear why birthweight is increased in some obese pregnancies but not in others. Maternal obesity is frequently studied using rodents on highfat diets, but effects on fetal growth are inconsistent. The purpose of this review is to identify factors that contribute to reduced or increased fetal growth in rodent models of maternal overnutrition.

Methods: We searched Web of Science and screened 2173 abstracts and 328 full texts for studies that fed mice or rats diets providing $\sim 45 \%$ or $\sim 60 \%$ calories from fat for 3 weeks or more prior to pregnancy. We identified 36 papers matching the search criteria that reported birthweight or fetal weight.

Results: Studies that fed $45 \%$ fat diets to mice or $60 \%$ fat diets to rats generally did not show effects on fetal growth. Feeding a $45 \%$ fat diet to rats generally reduced birth and fetal weight. Feeding mice a $60 \%$ fat diet for 4-9 weeks prior to pregnancy tended to increase in fetal growth, whereas feeding this diet for a longer period tended to reduce fetal growth.

Conclusions: The high-fat diets used most often with rodents do not closely match Western diets and frequently reduce fetal growth, which is not a typical feature of obese human pregnancies. Adoption of standard protocols that more accurately mimic effects on fetal growth observed in obese human pregnancies will improve translational impact in this field.
\end{abstract}

Keywords: Developmental origins, Fetal growth, Maternal nutrition, Obesity

\section{Background}

The prenatal environment has far reaching effects on health throughout life [1]. Among the first observations of such effects were associations between birthweight and risk of cardiovascular disease and diabetes [2-5]. Initial studies found associations between low birthweight and adverse health outcomes later in life, whereas subsequent studies found that both very low and very high birthweight increased the risk of adult disease [6-8]. As a result of these associations, there is enormous interest in the long-term consequences of maternal overnutrition and/ or obesity during pregnancy [9]. However, the effects of maternal obesity on birthweight remain poorly understood.

Studies consistently report that obese women are at higher risk of having a large-for-gestational-age (LGA) baby $[6,10]$. A higher frequency of LGA is due in part

\footnotetext{
* Correspondence: julian_christians@sfu.ca

Department of Biological Sciences, Simon Fraser University, 8888 University Drive, Burnaby, BC V5A 156, Canada
}

to obesity increasing the risk of gestational diabetes mellitus (GDM), which increases the risk of LGA [11]. However, maternal obesity also increases the risk of LGA in the absence of GDM [12]. Obese women are also at higher risk of hypertensive disorders of pregnancy such as preeclampsia, which is often associated with smallfor-gestational-age (SGA) neonates [11]. This observation suggests that obese mothers might be at higher risk of SGA as well, but such an association is not observed consistently $[13,14]$. There have been numerous reviews of the effects of dietary, exercise and lifestyle interventions on birthweight $[13,15-18]$, as well as associations between dietary intake and birthweight [13, 19-21]. However, these have not addressed why fetal growth is normal in many obese and diabetic pregnancies but altered in others [22].

Animal models are needed to better understand the effects of maternal obesity on fetal growth, and indeed numerous such studies have been performed, many 
using rodents fed high-fat diets (HFD). However, there is little standardization in this field, and the human phenotype being modeled is rarely defined more specifically than "obesity in pregnancy". While there are numerous reviews of the effects of maternal overnutrition and/ or obesity on offspring glycemic control [23] and cardiovascular health $[24,25]$ in animal models, to our knowledge there has been no review of the effects of maternal HFD on birthweight in rodents. Rodents are born at a different developmental stage than humans, with birth in rodents corresponding to the end of the second trimester/ beginning of the third trimester in humans [26]. Nevertheless, hundreds of studies use rodent pregnancy as a model of human pregnancy, and thus it is necessary to consider to what extent rodent models mimic humans with respect to fetal growth; rodent birthweight is expected to provide a model of human fetal growth over the first two trimesters.

The purpose of this review is to identify factors (macronutrient composition, duration of diet, strain, etc.) that contribute to reduced or increased fetal growth in rodent models of maternal overnutrition. Such a review is needed to enable the development of more relevant and standardized animal models of human phenotypes. We sought to identify factors that are common among animal models that report an increase or decrease in birthweight, and to assess the uniformity of studies that use similar models. Our aim was not to perform a meta-analysis to assess whether, on average, there was an effect of HFD on birthweight (e.g., [27]). Rather, our goal was to review studies with different methodologies to determine whether some manipulations yielded consistent effects on birthweight.

\section{Methods}

We followed the Preferred Reporting Items for Systematic Reviews and Meta-Analyses (PRISMA) guidelines [28].

\section{Data sources and search}

The Web of Science database was searched using the terms: (maternal OR gestational) AND diet AND (birth OR fetal) AND weight AND (mouse OR rat). An initial search was conducted on July 12th, 2016, and an updated search was conducted on July 4, 2018 (the latter including only studies from 2016 to 2018). Figure 1 shows the selection process.

\section{Eligibility criteria}

The participants, interventions, comparisons, outcomes, and study design (PICOS) criteria were as follows: participants were mice or rats; intervention was ad libitum access to a HFD during pregnancy (experimental diet may have also been provided prior to pregnancy, or may have been provided for only part of pregnancy); comparison was with a control diet provided ad libitum; outcome was birthweight (postnatal day 2 or earlier) or fetal weight of offspring from manipulated pregnancies (i.e., effects on subsequent generations were not included); study design was a controlled experiment. We included studies with any type of control diet that had a lower fat content than the intervention. Only studies published in English were included. Where more than one study appeared to describe the same dataset, only the first publication was included. Our updated, refined search added the following criteria: the HFD was provided for 3 weeks or more prior to pregnancy, and was either $44-45 \%$ calories from fat, or $57-62 \%$ calories from fat; cafeteria diets where animals were able to choose among food items were excluded.

\section{Study selection, data items and summary measures}

In the initial search, 1954 titles and abstracts were screened and the full texts of 275 papers were reviewed. 83 studies reporting the birth or fetal weight of offspring were identified (Fig. 1). From each of these, the following variables were recorded: percentage fat content in the HFD, source of additional fat in the HFD (plant vs. animal), duration of diet prior to pregnancy, sample size per group, and age of dams at mating. Fat contents expressed as percentage of calories from fat were recorded if available. Our summary measure was whether the maternal HFD led to a statistically significant increase or decrease in birth and/ or fetal weight.

In the updated search using refined criteria, 219 titles and abstracts were screened, and after removing studies already identified in the initial search, 53 full texts were reviewed. This yielded 11 new papers reporting birth or fetal weight of offspring and, together with studies from the initial search, 36 papers were identified that matched the refined criteria (Fig. 1). In addition to the information collected for the initial search, we also recorded how maternal weight was affected by the experimental diet, whether maternal glucose tolerance was affected, whether litter size was affected, and more information regarding the control diet.

We assumed that animals were assigned to experimental groups at random, and therefore that there was little risk of bias within individual studies. However, we acknowledge that there was likely a publication bias across studies, whereby statistically significant effects were more likely to be reported.

\section{Results}

The studies identified in the initial search, and the data extracted from each, are provided in Additional file 1: Table S1. Table 1 shows the number of studies finding an increase, decrease, or no effect on birthweight, aggregated by species, fat content, and duration of diet. More studies used rat than mouse as a model organism, and 


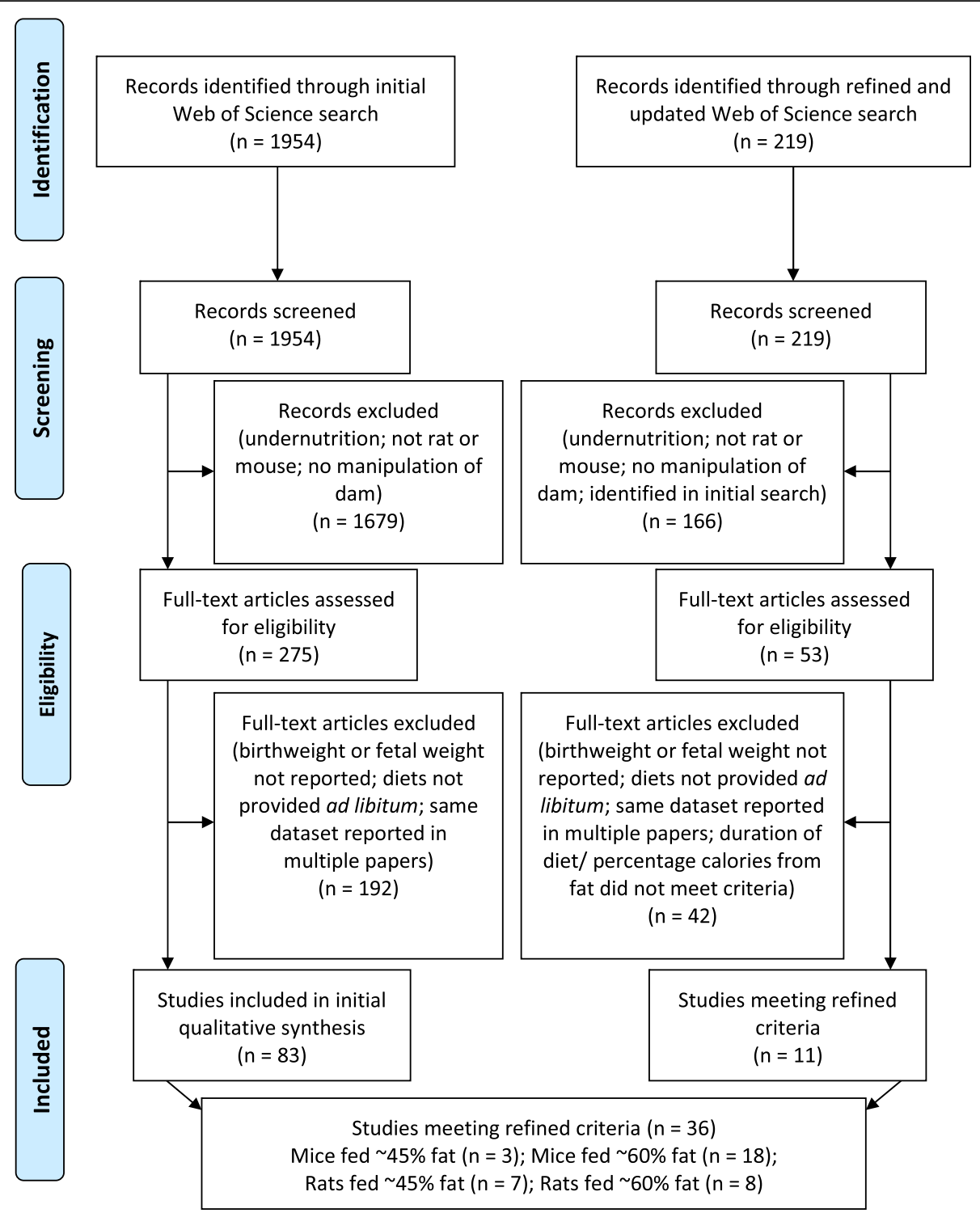

Fig. 1 Flow diagram showing the initial and refined searches (figure template from [28])

most used a HFD where the percentage of calories from fat was $45 \%$ or greater and included fat from animal sources (often lard) (Table 1, Additional file 1: Table S1). Among these studies, there were no consistent patterns with respect to effects on fetal growth. Increases and decreases were seen in studies of rats and mice, regardless of fat content, fat source or duration of diet prior to pregnancy. Although it might be expected that significant effects on birthweight would be found more often in studies with larger sample sizes, significant effects were approximately as frequent in studies with small sample sizes ( $<10$ dams per group) as in studies with moderate sample sizes (10-20 per group); few studies had greater than 20 dams per group (Additional file 1: Table S1).
The diversity of experimental designs makes comparisons among studies difficult, but studies which include more than one experimental group are useful for examining specific factors that influence the effect on birthweight. One study found that feeding rats diets containing 20 or $30 \%$ fat (by energy) from the start of gestation increased birthweight compared with a diet of $10 \%$ fat, whereas a $40 \%$ fat diet did not [69]. Work by the same group found that a $40 \%$ fat diet during the first week of pregnancy reduced birthweight, whereas the same diet fed throughout pregnancy did not [59]. In contrast, other work by this group found that the weight of 20 day-old fetuses was increased by a $40 \%$ fat diet administered in third week of gestation, but not by the same diet throughout gestation [80]. Work by a different group found that a 
Table 1 Summary of studies identified in initial search

\begin{tabular}{|c|c|c|c|c|c|c|}
\hline \multirow{2}{*}{$\begin{array}{l}\text { Experimental } \\
\text { protocol }\end{array}$} & \multirow{2}{*}{$\begin{array}{l}\text { Effect on } \\
\text { fetal } \\
\text { growth }\end{array}$} & \multicolumn{4}{|l|}{ Calories from fat } & \multirow[t]{2}{*}{ Total } \\
\hline & & $<45 \%$ & $45 \%$ & $>45 \%$ & Cafeteria & \\
\hline \multirow{6}{*}{$\begin{array}{l}\text { Rats fed high- } \\
\text { fat diet for } \\
3 \text { weeks or } \\
\text { more prior } \\
\text { to pregnancy }\end{array}$} & \multirow[t]{2}{*}{ Decrease } & \multirow[t]{2}{*}{0} & 4 & 2 & 4 & \multirow[t]{2}{*}{10} \\
\hline & & & $\begin{array}{l}\text { Nivoit et al. (2009) [29]; } \\
\text { Hayes et al. (2012) [30]; } \\
\text { Christante et al. (2013) } \\
\text { [31]; Reynolds et al. } \\
\text { (2014) [32] }\end{array}$ & $\begin{array}{l}\text { Couvreur et al. (2011) [33]; } \\
\text { Li et al. (2012) }\end{array}$ & $\begin{array}{l}\text { Akyol et al. (2009) [35]; } \\
\text { Raipuria et al. (2015) [36]; } \\
\text { Ramirez-Lopez et al. } \\
\text { (2016) [37]; Sánchez- } \\
\text { Blanco et al. (2016) [38] }\end{array}$ & \\
\hline & \multirow[t]{2}{*}{$\begin{array}{l}\text { No } \\
\text { effect }\end{array}$} & 3 & 2 & 8 & 3 & \multirow[t]{2}{*}{16} \\
\hline & & $\begin{array}{l}\text { Del Prado et al. (1997) } \\
\text { [39]; Caluwaerts et al. } \\
\text { 2007 [40]; Nitert et al. } \\
\text { (2013) [41] }\end{array}$ & $\begin{array}{l}\text { Zambrano et al. (2010) } \\
\text { [42]; Vega et al. } \\
(2015)^{\mathrm{b}}[43]\end{array}$ & $\begin{array}{l}\text { Shaw et al. (1997) }{ }^{\text {b }} \text { [44]; } \\
\text { Srinivasan et al. (2006) [45]; } \\
\text { Ferezou-Viala et al. (2007) [46]; } \\
\text { Gupta et al. (2009) [47]; } \\
\text { Mitra et al. (2009) [48]; } \\
\text { White et al. (2009) [49]; } \\
\text { Guberman et al. (2013) [50]; } \\
\text { Desai et al. (2014) [51] }\end{array}$ & $\begin{array}{l}\text { Rolls and Rowe (1982) } \\
\text { [52]; Chen et al. (2008) } \\
\text { [53]; Ong and Muhlhausler } \\
\text { (2011) [54] }\end{array}$ & \\
\hline & \multirow[t]{2}{*}{ Increase } & \multirow[t]{2}{*}{0} & 1 & 2 & 1 & \multirow[t]{2}{*}{4} \\
\hline & & & Song et al. (2015) [55] & $\begin{array}{l}\text { Gaccioli et al. (2013) })^{\mathrm{b}}[56] \\
\text { Mazzucco et al. (2013) [57] }\end{array}$ & Yang et al. (2015) [58] & \\
\hline \multirow{6}{*}{$\begin{array}{l}\text { Rats fed high- } \\
\text { fat diet for } \\
\text { less than } 3 \\
\text { weeks prior to } \\
\text { pregnancy }\end{array}$} & \multirow[t]{2}{*}{ Decrease } & 1 & 5 & 0 & 3 & \multirow[t]{2}{*}{9} \\
\hline & & Cerf et al. (2005) [59] & $\begin{array}{l}\text { Mark et al. (2011) [60]; } \\
\text { Smith et al. (2014) [61]; } \\
\text { Cordero et al. (2015) [62]; } \\
\text { Cunha et al. (2015) [63]; } \\
\text { Segovia et al. (2015) [64] }\end{array}$ & & $\begin{array}{l}\text { Bayol et al. (2007) [65]; } \\
\text { Zhang et al. (2011) [66]; } \\
\text { Gugusheff et al. (2013) } \\
\text { [67] }\end{array}$ & \\
\hline & \multirow[t]{2}{*}{$\begin{array}{l}\text { No } \\
\text { effect }\end{array}$} & 2 & 2 & 4 & 2 & \multirow[t]{2}{*}{10} \\
\hline & & $\begin{array}{l}\text { Martin et al. (1987) [68]; } \\
\text { Cerf et al. (2010) }{ }^{\mathrm{a}} \text { [69] }\end{array}$ & $\begin{array}{l}\text { Yang et al. (2012) [70]; } \\
\text { Tsoulis et al. (2016) [71] }\end{array}$ & $\begin{array}{l}\text { Ebesh et al. (1999) [72]; Walker } \\
\text { et al. (2008) }{ }^{\mathrm{b}} \text { [73]; Lin et al. } \\
(2011)^{\mathrm{b}} \text { [74]; de Oliveira } \\
\text { Andrade et al. (2014) [75] }\end{array}$ & $\begin{array}{l}\text { Rolls et al. (1984) [76]; } \\
\text { Zhang et al. (2013) [77] }\end{array}$ & \\
\hline & \multirow[t]{2}{*}{ Increase } & 4 & 1 & 1 & 1 & \multirow[t]{2}{*}{7} \\
\hline & & $\begin{array}{l}\text { Cerf et al. (2010) }{ }^{\mathrm{a}} \text { [69]; } \\
\text { Ferro Cavalcante et al. } \\
\text { (2013) [78]; Ferro } \\
\text { Cavalcante et al. (2014) } \\
\text { [79]; Cerf et al. (2015) [80] }\end{array}$ & Strakovsky et al. (2011) [81] & de Assis et al. (2006) ${ }^{b}$ [82] & $\begin{array}{l}\text { Kjaergaard et al. (2014) } \\
\text { [83] }\end{array}$ & \\
\hline $\begin{array}{l}\text { Total number } \\
\text { of rat studies }\end{array}$ & & $9^{a}$ & 15 & 17 & 14 & $55^{a}$ \\
\hline \multirow{6}{*}{$\begin{array}{l}\text { Mice fed } \\
\text { high-fat diet } \\
\text { for } 3 \text { weeks or } \\
\text { more prior to } \\
\text { pregnancy }\end{array}$} & \multirow[t]{2}{*}{ Decrease } & 1 & 0 & 7 & 0 & 8 \\
\hline & & \multicolumn{2}{|l|}{ Mayor et al. (2015) [84] } & $\begin{array}{l}\text { Niculescu and Lupu (2009) [85]; } \\
\text { Bentham et al. (2010) [86]; } \\
\text { King et al. (2013) [87]; King et al. } \\
\text { (2013) [88]; Sasson et al. (2015) } \\
\text { [89]; Edlow et al. (2016) [90]; } \\
\text { Panchenko et al. (2016) [91] }\end{array}$ & & \\
\hline & \multirow[t]{2}{*}{$\begin{array}{l}\text { No } \\
\text { effect }\end{array}$} & \multirow[t]{2}{*}{0} & 2 & 4 & 0 & \multirow[t]{2}{*}{6} \\
\hline & & & $\begin{array}{l}\text { Lager et al. (2014) }{ }^{\mathrm{b}} \text { [92]; } \\
\text { Umekawa et al. (2015) [93] }\end{array}$ & $\begin{array}{l}\text { Liang et al. (2009) [94]; } \\
\text { Bytautiene et al. (2011) [95]; } \\
\text { King et al. (2013) }[88] \text {; } \\
\text { Murabayashi et al. (2013) [96] }\end{array}$ & & \\
\hline & \multirow[t]{2}{*}{ Increase } & 2 & 0 & 5 & 0 & \multirow[t]{2}{*}{7} \\
\hline & & $\begin{array}{l}\text { Aye et al. (2015) [97]; } \\
\text { Rosario et al. (2015) [98] }\end{array}$ & & $\begin{array}{l}\text { Masuyama and Hiramatsu } \\
\text { (2012) [99]; Masuyama and } \\
\text { Hiramatsu (2012) [100]; }\end{array}$ & & \\
\hline
\end{tabular}


Table 1 Summary of studies identified in initial search (Continued)

\begin{tabular}{|c|c|c|c|c|c|c|}
\hline \multirow{2}{*}{$\begin{array}{l}\text { Experimental } \\
\text { protocol }\end{array}$} & \multirow{2}{*}{$\begin{array}{l}\text { Effect on } \\
\text { fetal } \\
\text { growth }\end{array}$} & \multicolumn{4}{|l|}{ Calories from fat } & \multirow[t]{2}{*}{ Total } \\
\hline & & $<45 \%$ & $45 \%$ & $>45 \%$ & Cafeteria & \\
\hline & & & & $\begin{array}{l}\text { Dahlhoff et al. (2014) [101]; } \\
\text { Masuyama and } \\
\text { Hiramatsu (2014) [102]; } \\
\text { Masuyama et al. (2015) [103] }\end{array}$ & & \\
\hline \multirow{6}{*}{$\begin{array}{l}\text { Mice fed } \\
\text { high-fat diet } \\
\text { for less than } \\
3 \text { weeks prior } \\
\text { to pregnancy }\end{array}$} & Decrease & 1 & 1 & 1 & 0 & 3 \\
\hline & & $\begin{array}{l}\text { Sferruzzi-Perri et al. } \\
(2013)^{a}[104]\end{array}$ & Turdi et al. (2013) [105] & del Mar Plata et al. (2014) [106] & & \\
\hline & $\begin{array}{l}\text { No } \\
\text { effect }\end{array}$ & 1 & 2 & 1 & 0 & 4 \\
\hline & & $\begin{array}{l}\text { Sferruzzi-Perri et al. } \\
(2013)^{a}[104]\end{array}$ & $\begin{array}{l}\text { Luijten et al. }(2013)^{\mathrm{b}}[107] \text {; } \\
\text { Benatti et al. (2014) [108] }\end{array}$ & Volpato et al. (2012) [109] & & \\
\hline & Increase & 0 & 1 & 1 & 0 & 2 \\
\hline & & & Ashino et al. (2012) [110] & Gregorio et al. (2013) [111] & & \\
\hline $\begin{array}{l}\text { Total number } \\
\text { of mouse } \\
\text { studies }^{\mathrm{a}}\end{array}$ & & $4^{\mathrm{a}}$ & 6 & $18^{\mathrm{a}}$ & 0 & $28^{\mathrm{a}}$ \\
\hline
\end{tabular}

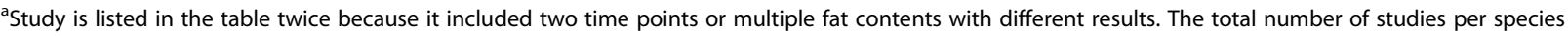
counts each study only once

bercentage of calories from fat was estimated based on energy density of diet, using values from two Research Diets (New Brunswick, NJ) diets (D12451: 45\% fat by calories, $4.7 \mathrm{kcal} / \mathrm{g}, 24 \%$ fat by weight, and $\mathrm{D} 12492: 60 \%$ fat by calories, $5.21 \mathrm{kcal} / \mathrm{g}, 35 \%$ fat by weight)

cafeteria diet fed to rats for 8 weeks prior to pregnancy reduced fetal weight at day 20 , whereas the same diet fed from the start of pregnancy did not [35].

Effects of a maternal HFD may be consistent across gestational ages $[89,93,101]$ but may vary through pregnancy. A diet high in fat and simple sugars fed to female mice from the beginning pregnancy reduced fetal weight at G15.5 but not G18.5 [104]. In contrast, a diet with a much higher fat content, and also high in simple sugars, fed to female mice for 12 weeks prior to pregnancy had no effect fetal weight at 14.5 but reduced fetal weight in day 18.5 male fetuses but not female fetuses [88]. Work by the same group found that the same protocol reduced birthweight in females but not males [87]. Inconsistencies in sex-specific effects may arise if the differences between males and females are not tested explicitly, e.g., using a sex by treatment interaction [112]. Studies by a single lab group using the same protocol may yield results that are similar $[99,100,103]$ or divergent $[66,77]$.

Our initial survey did not reveal factors associated with maternal overnutrition that consistently led to increased or decreased fetal growth. We therefore focused more closely on a subset of studies with similar protocols and updated our search. Specifically, we focused on studies using HFDs containing $44-45 \%$ fat or $57-62 \%$ fat (by energy), as these were relatively numerous. We also restricted this refined search to studies that initiated experimental diets 3 weeks or more prior to pregnancy to include effects of maternal obesity rather than gestational overnutrition alone.

The studies identified in the refined search are summarized in Table 2, and the data extracted from each are provided in Additional file 1: Table S2. Our refined search found only 3 studies that fed mice a $45 \%$ fat diet, and all of these reported no effect on birth and/or fetal weight $[93,119,120]$. These studies had very similar protocols, using the same mouse strain $(\mathrm{C} 57 \mathrm{BL} / 6)$, the same HFD from the same manufacturer, and similar nutrient-matched $10 \%$ fat control diets (although these varied in sucrose content). The effect of a $58-60 \%$ diet on C57BL/6 mice was more variable, with 7 finding that HFD reduced birth and/or fetal weight [85, 87-91, 118], 3 finding no effect [94, 96, 121], and only one finding increased fetal weight [123], although the latter measured fetal weight much earlier than the others (at G12.5). Many of these studies used the same HFD from the same manufacturer, and some used nutrient-controls while others used chow as a control diet. However, even studies using identical HFD and control diets yielded divergent results (e.g., $[85,96]$ or $[90,123])$. Among other mouse strains, the effects of a $60-62 \%$ fat diet increased birth and/or fetal weight in 6 studies [99-103, 122], although 5 of these were from the same group, and one study found no effect [95]. Among studies feeding 60\% fat diets to mice, those finding an increase in fetal growth had fed the experimental diet for a shorter duration prior to pregnancy (4-9 weeks) than those reporting a reduction in fetal growth (9 weeks or more) (Additional file 1: Table S2). There was variability in the sucrose content of the control diets, but this was not associated with effects on birthweight (Additional file 1: Table S2).

Rats fed a $45 \%$ fat diet generally had offspring with reduced birth and/or fetal weights [29, 30, 32, 113-115], 
Table 2 Summary of studies identified in the updated and refined search

\begin{tabular}{|c|c|c|c|c|}
\hline \multirow[t]{2}{*}{ Species } & \multirow{2}{*}{$\begin{array}{l}\text { Effect on } \\
\text { fetal } \\
\text { growth }\end{array}$} & \multicolumn{2}{|l|}{ Calories from fat } & \multirow[t]{2}{*}{ Tota } \\
\hline & & $\sim 45 \%$ & $\sim 60 \%$ & \\
\hline \multirow[t]{6}{*}{ Rat } & Decrease & 6 & 1 & 7 \\
\hline & & $\begin{array}{l}\text { Nivoit et al. (2009) [29]; } \\
\text { Hayes et al. (2012) [30]; } \\
\text { Reynolds et al. (2014) } \\
\text { [32]; Dodson et al. } \\
\text { (2017) [113]; Huang et al. } \\
\text { (2017) [114]; Ye et al. } \\
\text { (2017) [115] }\end{array}$ & $\begin{array}{l}\text { Yamada-Obara et al. } \\
\text { (2016) [116] }\end{array}$ & \\
\hline & No effect & 0 & 7 & 7 \\
\hline & & & $\begin{array}{l}\text { Srinivasan et al. (2006) [45]; } \\
\text { Gupta et al. (2009) [47]; } \\
\text { Mitra et al. (2009) [48]; } \\
\text { White et al. (2009) [49]; } \\
\text { Guberman et al. (2013) [50]; } \\
\text { Desai et al. (2014) [51]; } \\
\text { Lecoutre et al. (2016) [117] }\end{array}$ & \\
\hline & Increase & 1 & 0 & 1 \\
\hline & & Song et al. (2015) [55] & & \\
\hline Total & & 7 & 8 & 15 \\
\hline \multirow[t]{6}{*}{ Mouse } & Decrease & 0 & 7 & 7 \\
\hline & & & $\begin{array}{l}\text { Niculescu and Lupu (2009) } \\
\text { [85]; King et al. (2013) [87]; } \\
\text { King et al. (2013) [88]; } \\
\text { Sasson et al. (2015) [89]; } \\
\text { Edlow et al. (2016) [90]; } \\
\text { Panchenko et al. (2016) } \\
\text { [91]; Bae-Gartz et al. } \\
\text { (2016) [118] }\end{array}$ & \\
\hline & No effect & 3 & 5 & 8 \\
\hline & & $\begin{array}{l}\text { Umekawa et al. (2015) [93]; } \\
\text { Chin et al. (2017) [119]; } \\
\text { Jonscher et al. (2017) [120] }\end{array}$ & $\begin{array}{l}\text { Liang et al. (2009) [94]; } \\
\text { Bytautiene et al. (2011) } \\
\text { [95]; King et al. (2013) } \\
\text { [88]; Murabayashi et al. } \\
\text { (2013) [96]; Connor } \\
\text { et al. (2018) [121] }\end{array}$ & \\
\hline & Increase & 0 & 7 & 7 \\
\hline & & & $\begin{array}{l}\text { Masuyama and Hiramatsu } \\
\text { (2012) [99]; Masuyama } \\
\text { and Hiramatsu (2012) } \\
\text { [100]; Dahlhoff et al. (2014) } \\
\text { [101]; Masuyama and } \\
\text { Hiramatsu (2014) [102]; } \\
\text { Masuyama et al. (2015) } \\
\text { [103]; Masuyama et al. } \\
\text { (2016) [122]; Nam et al. } \\
\text { (2017) [123] }\end{array}$ & \\
\hline Total $^{a}$ & & 3 & $18^{\mathrm{a}}$ & $21^{\mathrm{a}}$ \\
\hline
\end{tabular}

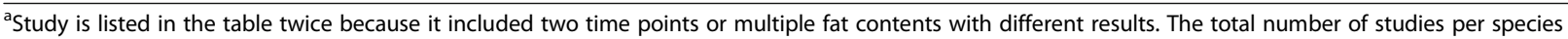
counts each study only once

although the only study that used a nutrient-matched control diet showed an increase in birthweight [55]. In contrast, feeding rats a $57-60 \%$ fat diet generally had no effect on birth or fetal weight [45, 47-51, 117], although one study, which also provided fructose in the water of dams on the HFD, found a reduction in birthweight [116]. Variation between studies was not due to strain, as most used Sprague-Dawley rats, and discordant results were observed with this strain.

In both mice and rats fed diets of $\sim 45 \%$ fat or $\sim 60 \%$ fat, the HFD generally increased maternal mass prior to conception and impaired glucose tolerance, at least when these 
parameters were reported (Additional file 1: Table S2). In one case, impaired glucose tolerance was observed in HFD-fed females even though the control diet had a higher sucrose content [96]. Given that mice and rats gestate multiple fetuses per pregnancy, fetal growth might be influenced by effects on litter size, e.g., a reduction in litter size would be expected to increase the growth of individual fetuses. However, most studies that reported litter size found no effects of maternal HFD (Additional file 1: Table S2), and some found reductions in both litter size and the weight of individual offspring [30, 85, 87].

\section{Discussion}

Rodents fed HFD are frequently used to study the effects of maternal obesity on offspring health, but we found few consistent effects of maternal HFD on fetal growth. The importance of these findings is not diminished by the fact that rodents are born at a different developmental stage than humans; a rodent model that decreases fetal growth and another that increases fetal growth cannot both model the same human phenotype. Our initial search identified studies with a variety of experimental protocols, and this revealed no clear patterns with respect to how the effects of maternal HFD depend on species, duration of diet, or diet composition. When we refined our focus to studies that fed dams diets containing $\sim 45 \%$ fat or $\sim 60 \%$ fat (by energy) for 3 weeks or more prior to pregnancy, we found more consistent results. Mice fed $45 \%$ fat diets and rats fed $60 \%$ fat diets generally did not show effects on fetal growth. Feeding a $45 \%$ fat diet to rats generally reduced birth and fetal weight. However, results were more variable in mice fed a $60 \%$ fat diet, with studies feeding the HFD for shorter periods prior to pregnancy (4-9 weeks) more likely to report an increase in fetal growth, whereas those feeding for a longer period were more likely to report a reduction in fetal growth.

Some variability among similar studies is not surprising. Thousands of studies have used rodents fed HFD to study obesity and/or diabetes (not specifically in pregnancy), and effects on weight gain and glycemic control have been inconsistent. Effects depend on diet composition, duration of diet, age and strain of animal, and in some cases vary among different experiments from the same lab [124]. The nature of the control diet is also important, since studies that use chow as controls may differ from a defined HFD in terms of protein source and fiber in addition to fat $[124,125]$.

A variety of models are needed given that there are a variety of diets and lifestyle characteristics associated with human obesity. However, the translation of the results of animal studies to clinical practice and policy development would benefit from some standardization of models and/or more explicit relation of the model to a particular human phenotype. Below, we discuss three key issues to consider in the design of experiments to examine the long-term consequences of maternal overnutrition and/ or obesity, and provide recommendations for standardized models.

\section{Experimental diets and controls}

The percentage of energy from fat in US diets is estimated to be in the range of $30-40 \%$ in obese and normal weight individuals [124, 126, 127], and therefore experimental diets with much more than $40 \%$ of energy from fat may provide weaker models of human pathophysiology. Similarly, the median percentage of calories from protein in US diets is 14\% [128], whereas many of the studies that we identified used purified HFDs that were $20 \%$ protein, although some attempted to mimic the protein content of Western diets [113, 129]. Thus, while many experimental diets are successful in increasing maternal pre-pregnancy weight and/ or impairing glucose metabolism, the resulting obesity may not accurately reflect common human phenotypes. To facilitate putting experimental diets into a human context, studies should be required to report the macronutrient composition of experimental and control diets as a percentage of total energy, rather than only reporting contents by weight and/ or the overall energy density.

Although we focused on studies that provided a HFD ad libitum for a specific period prior to and/or during pregnancy, we acknowledge that other experimental approaches offer advantages for studying the effects of maternal obesity. Embryo transfers have been used to distinguish the effects of pre-gestational and gestational exposure to maternal obesity [89]. Shankar et al. [130] fed liquid diets to rats by intragastric cannulation to induce obesity by controlling the number of calories provided. A contrasting approach is to control food intake to keep energy consumption similar and vary only the macronutrient composition of the maternal diet [131]. To ensure that the HFD induces maternal obesity, some studies mate HFD females when their body weight has increased by a certain amount, and compare these with age-matched females on a control diet. In mice, this approach increased fetal weight in two studies [97, 98], had no effect in another [132], and decreased fetal weight in a fourth [90]. Ye et al. [115] fed rats a HFD and selected those with the greatest weight gain (susceptible to diet-induced obesity) and those with the lowest weight gain (resistant to diet-induced obesity) and found that fetal weight was reduced in susceptible dams but not in resistant dams.

\section{Effects on birthweight}

It is concerning that a substantial number of studies found that a maternal HFD reduced fetal growth, because this is 
not a typical feature of obese pregnancy in humans. Although some reviews suggest that obese mothers are at increased risk of delivering small infants, closer scrutiny of the primary literature cited does not support such claims. To the contrary, some studies have found that obesity reduces the risk of delivering a small-for-gestational age or low-birthweight baby [133-136]. Obesity increases the risk of preeclampsia, and preeclampsia is often associated with intrauterine growth restriction [11, 137] but it does not necessarily follow that obesity increases the risk of intrauterine growth restriction. Studies reporting increased risk of preeclampsia in obese pregnancies generally do not find associations between obesity and IUGR $[138,139]$. We know of only one study that found an increased risk of having a small-for-gestational-age infant among obese women, and this was found only in association with a body mass index (BMI) over 40, and not with a BMI of 29-40 [140]. The association was not significant after removing women with preeclampsia [140], suggesting that obesity specifically increased the risk of growth restriction in preeclamptic women. Thus, apart from this study, there is little evidence that human obesity is associated with fetal growth restriction. Therefore, experimental approaches that result in reduced fetal growth are less relevant as models of obesity and overnutrition in humans, and it may be useful to avoid the protocols that we have identified as consistently reducing fetal growth. Based on developmental milestones, rodent birthweight only provides a model of human fetal growth up to the end of the second trimester. However, it is unlikely that a rodent model with reduced birthweight is a good model for an obese human pregnancy with an increased risk of high birthweight, unless it can be shown that human obesity results in growth restriction early in pregnancy that recovers in the last trimester. Experimental approaches that increase fetal growth are suitable for modeling high birthweights, which occurs at higher frequency in obese pregnancies [6, 10]. Mating HFD mice when their weight had increased by $25 \%$ led to higher fetal weight in two studies $[97,98]$ but had no effect in another [132]. While the solid component of the HFD was $41 \%$ fat in these studies, the provision of a sucrose solution with the HFD would have reduced the percentage of calories from fat (and protein), perhaps to levels more typical of Western diets. Protocols with no effect on fetal growth may be useful for studying effects of maternal obesity on offspring health that occur independently of birthweight [141].

\section{Species and strain}

As model species, rats and mice offer different strengths and weaknesses. The larger size of rats facilitates various physiological manipulations and measurements, while mice are more amenable to genetic manipulation, and their smaller size reduces cost per animal [142]. Rat strains are generally outbred (Wistar, Sprague Dawley, Long-Evans) while the most commonly used mouse strains (e.g., C57BL/6) are inbred [143]. While inbred strains reduce variability and thereby increase the power to detect certain effects, outbred strains may provide a better model of the genetic heterogeneity of human populations [25], and may also be of greater relevance for effects dependent on the immune system [142].

In a recent meta-analysis, maternal HFD tended to increase birthweight in mice and decrease birthweight in rats, although species and strain contributed relatively little to between-study variability in the metabolic effects of maternal HFD [27]. Strains of mice differ in their susceptibility to the metabolic effects of HFD [144], but it is not necessarily the case that more susceptible strains are better models; more resistant strains may offer the opportunity to study differences between obesity-susceptible and obesity-resistant individuals (e.g., [115]). Glucose metabolism even differs between substrains of C57BL/6 [145], which underscores the importance of reporting the substrain, e.g., C57BL/6 J vs. C57BL/6 N.

While mice and rats are frequently used to investigate the effects of maternal nutrition, these species are born at a substantially different developmental stage than humans and generally have multiple fetuses per pregnancy. In these and some other respects, other rodent models such as guinea pigs offer advantages over mice and rats [146]. A more complete consideration of species selection is provided elsewhere [142, 147]. As with the diet protocol, the rationale for the choice of species and the specific situation it attempts to model should be described explicitly [142]. Nevertheless, there are broad similarities in the phenotypes of offspring exposed to maternal HFD between mice, rats and nonhuman primates [143].

\section{Conclusions}

The effects of HFD during pregnancy have been examined with a diverse array of experimental protocols yielding few clear patterns with respect to approaches that increase or decrease fetal growth. However, studies with similar protocols using the same strain of animal yield more consistent results. Even so, the HFD used most frequently with rodents do not closely match Western diets, the former being higher in fat and protein. Perhaps for this reason, many studies find that a maternal HFD reduces fetal growth in rodents, which is not a typical feature of obese human pregnancies. The present review has identified experimental approaches that increase birthweight or have no effect, and the adoption and standardization of such protocols will improve the translational impact of research into the effects of maternal overnutrition on offspring health. 


\section{Additional file}

Additional file 1: Table S1. Studies identified in the initial search; Table S2. Studies identified in the refined search. (XLSX $32 \mathrm{~kb}$ )

\section{Abbreviations}

BMI: Body mass index; GDM: Gestational diabetes mellitus; HFD: High fat diet; LGA: Large-for-gestational-age

\section{Acknowledgements}

None.

\section{Funding}

This study was funded by a Natural Sciences and Engineering Research Council of Canada Discovery Grant (JKC; grant number RGPIN-2016-04047) and a Simon Fraser University Vice President, Research Undergraduate Student Research Award (KIL). The funding bodies had no role in study design, collection and interpretation of data or in manuscript preparation.

\section{Availability of data and materials}

This review was based on published data.

\section{Authors' contributions}

JKC conceived of the study, contributed to the extraction of data from studies matching search criteria, and wrote the manuscript. KIL, LKW and RG performed the literature searches and screens of titles and abstracts, extracted data from studies matching search criteria, and helped draft the manuscript. All authors read and approved the final manuscript.

\section{Ethics approval and consent to participate}

This review study was based on published work and therefore did not require approval by an institutional committee.

\section{Consent for publication}

Not applicable.

\section{Competing interests}

The authors declare that they have no competing interests.

\section{Publisher's Note}

Springer Nature remains neutral with regard to jurisdictional claims in published maps and institutional affiliations.

\section{Received: 9 October 2018 Accepted: 9 April 2019}

Published online: 16 April 2019

\section{References}

1. Hoffman DJ, Reynolds RM, Hardy DB. Developmental origins of health and disease: current knowledge and potential mechanisms. Nutr Rev. 2017:75:951-70

2. Barker DJP, Osmond C, Kajantie E, Eriksson JG. Growth and chronic disease: findings in the Helsinki birth cohort. Ann Hum Biol. 2009:36:444-58.

3. Barker DJP, Osmond C, Winter PD, Margetts B, Simmonds SJ. Weight in infancy and death from ischaemic heart disease. Lancet. 1989;334:577-80.

4. Barker DJ, Bull AR, Osmond C, Simmonds SJ. Fetal and placental size and risk of hypertension in adult life. BMJ. 1990:301:259-62.

5. Hales CN, Barker DJP, Clark PMS, Cox LJ, Osmond C, Winter PD. Fetal and infant growth and impaired glucose tolerance at age $64 . \mathrm{Br}$ Med $\mathrm{J}$. 1991;303:1019-22.

6. Sen S, Carpenter AH, Hochstadt J, Huddleston JY, Kustanovich V, Reynolds $A A$, et al. Nutrition, weight gain and eating behavior in pregnancy: a review of experimental evidence for long-term effects on the risk of obesity in offspring. Physiol Behav. 2012;107:138-45.

7. Hanson MA, Gluckman PD. Early developmental conditioning of later health and disease: physiology or pathophysiology? Physiol Rev. 2014;94:1027-76.

8. Grissom NM, Reyes TM. Gestational overgrowth and undergrowth affect neurodevelopment: similarities and differences from behavior to epigenetics. Int J Dev Neurosci. 2013;31:406-14.
9. Li M, Sloboda DM, Vickers MH. Maternal obesity and developmental programming of metabolic disorders in offspring: evidence from animal models. Exp Diabetes Res. 2011;2011:592408.

10. Yu Z, Han S, Zhu J, Sun X, Ji C, Guo X. Pre-pregnancy body mass index in relation to infant birth weight and offspring overweight/obesity: a systematic review and meta-analysis. PLoS One. 2013:8:e61627.

11. Howell KR, Powell TL. Effects of maternal obesity on placental function and fetal development. Reproduction. 2017;153:R97-108.

12. Dennedy MC, Avalos G, O'Reilly MW, O'Sullivan EP, Gaffney G, Dunne F. ATLANTIC-DIP: raised maternal body mass index (BMI) adversely affects maternal and fetal outcomes in glucose-tolerant women according to International Association of Diabetes and Pregnancy Study Groups (IADPSG) criteria. J Clin Endocrinol Metab. 2012;97:E608-12.

13. Grieger JA, Clifton VL. A review of the impact of dietary intakes in human pregnancy on infant birthweight. Nutrients. 2015;7:153-78.

14. Stang J, Huffman LG. Position of the academy of nutrition and dietetics: obesity, reproduction, and pregnancy outcomes. J Acad Nutr Diet. 2016;116:677-91.

15. Tanentsapf I, Heitmann BL, Adegboye ARA. Systematic review of clinical trials on dietary interventions to prevent excessive weight gain during pregnancy among normal weight, overweight and obese women. BMC Pregnancy Childbirth. 2011:11:81.

16. Nathanielsz PW, Ford SP, Long NM, Vega CC, Reyes-Castro LA, Zambrano E. Interventions to prevent adverse fetal programming due to maternal obesity during pregnancy. Nutr Rev. 2013;71:S78-87.

17. Oteng-Ntim E, Varma R, Croker H, Poston L, Doyle P. Lifestyle interventions for overweight and obese pregnant women to improve pregnancy outcome: systematic review and meta-analysis. BMC Med. 2012;10:47.

18. Gresham E, Byles JE, Bisquera A, Hure AJ. Effects of dietary interventions on neonatal and infant outcomes: a systematic review and meta-analysis. Am J Clin Nutr. 2014;100:1298-321.

19. Murphy MM, Stettler N, Smith KM, Reiss R. Associations of consumption of fruits and vegetables during pregnancy with infant birth weight or small for gestational age births: a systematic review of the literature. Int J Women's Health. 2014:6:899-912.

20. McGee M, Bainbridge S, Fontaine-Bisson B. A crucial role for maternal dietary methyl donor intake in epigenetic programming and fetal growth outcomes. Nutr Rev. 2018;76:469-78.

21. Pannia E, Cho CE, Kubant R, Sanchez-Hernandez D, Huot PSP, Anderson GH. Role of maternal vitamins in programming health and chronic disease. Nutr Rev. 2016;74:166-80.

22. Lewis RM, Demmelmair H, Gaillard R, Godfrey KM, Hauguel-De Mouzon S, Huppertz B, et al. The placental exposome: Placental determinants of fetal adiposity and postnatal body composition. Ann Nutr Metab. 2013;63:208-15.

23. Ainge $\mathrm{H}$, Thompson C, Ozanne SE, Rooney KB. A systematic review on animal models of maternal high fat feeding and offspring glycaemic control. Int J Obes. 2011;35:325-35.

24. Blackmore HL, Ozanne SE. Maternal diet-induced obesity and offspring cardiovascular health. J Dev Orig Health Dis. 2013;4:338-47.

25. Morton JS, Cooke C-L, Davidge ST. In utero origins of hypertension: mechanisms and targets for therapy. Physiol Rev. 2016;96:549-603.

26. Semple BD, Blomgren K, Gimlin K, Ferriero DM, Noble-Haeusslein LJ. Brain development in rodents and humans: identifying benchmarks of maturation and vulnerability to injury across species. Prog Neurobiol. 2013;106-107:1-16.

27. Ribaroff GA, Wastnedge E, Drake AJ, Sharpe RM, Chambers TJG. Animal models of maternal high fat diet exposure and effects on metabolism in offspring: a meta-regression analysis. Obes Rev. 2017;18:673-86.

28. Moher D, Liberati A, Tetzlaff J, Altman DG, The PRISMA Group. Preferred reporting items for systematic reviews and meta-analyses: The PRISMA statement. PLoS Med. 2009;6:e1000097.

29. Nivoit P, Morens C, Van Assche FA, Jansen E, Poston L, Remacle C, et al. Established diet-induced obesity in female rats leads to offspring hyperphagia, adiposity and insulin resistance. Diabetologia. 2009:52:1133-42.

30. Hayes EK, Lechowicz A, Petrik JJ, Storozhuk Y, Paez-Parent S, Dai Q, et al. Adverse fetal and neonatal outcomes associated with a life-long high fat diet: role of altered development of the placental vasculature. PLoS One. 2012;7:e33370.

31. Christante CM, Taboga SR, Pinto-Fochi ME, Goes RM. Maternal obesity disturbs the postnatal development of gonocytes in the rat without impairment of testis structure at prepubertal age. Reproduction. 2013:146:549-58.

32. Reynolds CM, Vickers MH, Harrison CJ, Segovia SA, Gray C. High fat and/or high salt intake during pregnancy alters maternal meta-inflammation and offspring growth and metabolic profiles. Physiol Rep. 2014;2:e12110. 
33. Couvreur O, Ferezou J, Gripois D, Serougne C, Crepin D, Aubourg A, et al. Unexpected Long-term protection of adult offspring born to high-fat fed dams against obesity induced by a sucrose-rich diet. PLoS One. 2011;6:e18043.

34. Li S, Tse IMY, Li ETS. Maternal green tea extract supplementation to rats fed a high-fat diet ameliorates insulin resistance in adult male offspring. J Nutr Biochem. 2012;23:1655-60.

35. Akyol A, Langley-Evans SC, McMullen S. Obesity induced by cafeteria feeding and pregnancy outcome in the rat. Br J Nutr. 2009;102:1601-10.

36. Raipuria M, Bahari $\mathrm{H}$, Morris MJ. Effects of maternal diet and exercise during pregnancy on glucose metabolism in skeletal muscle and fat of weanling rats. PLoS One. 2015;10:e0120980.

37. Ramirez-Lopez MT, Vazquez M, Bindila L, Lomazzo E, Hofmann C, Blanco RN et al. Exposure to a highly caloric palatable diet during Pregestational and gestational periods affects hypothalamic and hippocampal endocannabinoid levels at birth and induces adiposity and anxiety-like behaviors in male rat offspring. Front Behav Neurosci. 2016;9:339.

38. Sánchez-Blanco C, Amusquivar E, Bispo K, Herrera E. Influence of cafeteria diet and fish oil in pregnancy and lactation on pups' body weight and fatty acid profiles in rats. Eur J Nutr. 2016;55:1741-53.

39. DelPrado M, Delgado G, Villalpando S. Maternal lipid intake during pregnancy and lactation alters milk composition and production and litter growth in rats. J Nutr. 1997;127:458-62.

40. Caluwaerts S, Lambin S, van Bree R, Peeters H, Vergote I, Verhaeghe J. Dietinduced obesity in gravid rats engenders early hyperadiposity in the offspring. Metab Exp. 2007;56:1431-8.

41. Nitert MD, Vaswani K, Hum M, Chan H-W, Wood-Bradley R, Henry S, et al. Maternal high-fat diet alters expression of pathways of growth, blood supply and arachidonic acid in rat placenta. J Nutr Sci. 2013;2:e41.

42. Zambrano E, Martinez-Samayoa PM, Rodriguez-Gonzalez GL, Nathanielsz PW. Dietary intervention prior to pregnancy reverses metabolic programming in male offspring of obese rats. J Physiol. 2010;588:1791-9.

43. Vega CC, Reyes-Castro LA, Bautista CJ, Larrea F, Nathanielsz PW, Zambrano E. Exercise in obese female rats has beneficial effects on maternal and male and female offspring metabolism. Int J Obes. 2015;39:712-9.

44. Shaw MA, Rasmussen KM, Myers TR. Consumption of a high fat diet impairs reproductive performance in Sprague-Dawley rats. J Nutr. 1997;127:64-9.

45. Srinivasan M, Katewa SD, Palaniyappan A, Pandya JD, Patel MS. Maternal high-fat diet consumption results in fetal malprogramming predisposing to the onset of metabolic syndrome-like phenotype in adulthood. Am J Physiol Metab. 2006;291:E792-9.

46. Ferezou-Viala J, Roy A-F, Serougne C, Gripois D, Parquet M, Bailleux V, et al Long-term consequences of maternal high-fat feeding on hypothalamic leptin sensitivity and diet-induced obesity in the offspring. Am J Physiol Integr Comp Physiol. 2007;293:R1056-62.

47. Gupta A, Srinivasan M, Thamadilok S, Patel MS. Hypothalamic alterations in fetuses of high fat diet-fed obese female rats. J Endocrinol. 2009:200:293-300.

48. Mitra A, Alvers KM, Crump EM, Rowland NE. Effect of high-fat diet during gestation, lactation, or postweaning on physiological and behavioral indexes in borderline hypertensive rats. Am J Physiol Integr Comp Physiol. 2009;296:R20-8.

49. White $\mathrm{CL}$, Purpera MN, Morrison CD. Maternal obesity is necessary for programming effect of high-fat diet on offspring. Am J Physiol Integr Comp Physiol. 2009;296:R1464-72.

50. Guberman C, Jellyman JK, Han G, Ross MG, Desai M. Maternal high-fat diet programs rat offspring hypertension and activates the adipose reninangiotensin system. Am J Obstet Gynecol. 2013;209:262.e1-8.

51. Desai M, Jellyman JK, Han G, Beall M, Lane RH, Ross MG. Maternal obesity and high-fat diet program offspring metabolic syndrome. Am J Obstet Gynecol. 2014;211:237.e1-237.e13.

52. Rolls BJ, Rowe EA. Pregnancy and lactation in the obese rat - effects on maternal and pup weights. Physiol Behav. 1982;28:393-400.

53. Chen H, Simar D, Lambert K, Mercier J, Morris MJ. Maternal and postnatal Overnutrition differentially impact appetite regulators and fuel metabolism. Endocrinology. 2008;149:5348-56

54. Ong ZY, Muhlhausler BS. Maternal "junk-food" feeding of rat dams alters food choices and development of the mesolimbic reward pathway in the offspring. FASEB J. 2011:25:2167-79.

55. Song Y, Yu Y, Wang D, Chai S, Liu D, Xiao X, et al. Maternal high-fat diet feeding during pregnancy and lactation augments lung inflammation and remodeling in the offspring. Respir Physiol Neurobiol. 2015;207:1-6.
56. Gaccioli F, White V, Capobianco E, Powell TL, Jawerbaum A, Jansson T. Maternal overweight induced by a diet with high content of saturated fat activates placental mTOR and elF2alpha signaling and increases fetal growth in rats. Biol Reprod. 2013;89:96.

57. Mazzucco MB, Higa R, Capobianco E, Kurtz M, Jawerbaum A, White V. Saturated fat-rich diet increases fetal lipids and modulates LPL and leptin receptor expression in rat placentas. J Endocrinol. 2013;217:303-15.

58. Yang X, Lai P, Chen X-G, Liu Z-P, Tang Y-M, Rao S, et al. Maternal high-fat diet exposure leads to insulin resistance and impacts myogenic and adipogenicgene expression in offspring rats. Eur J Lipid Sci Technol. 2015;117:1550-60.

59. Cerf ME, Williams K, Nkomo XI, Muller CJ, Du Toit DF, Louw J, et al. Islet cell response in the neonatal rat after exposure to a high-fat diet during pregnancy. Am J Physiol Integr Comp Physiol. 2005;288:R1122-8.

60. Mark PJ, Sisala C, Connor K, Patel R, Lewis JL, Vickers MH, et al. A maternal high-fat diet in rat pregnancy reduces growth of the fetus and the placental junctional zone, but not placental labyrinth zone growth. J Dev Orig Health Dis. 2011;2:63-70.

61. Smith T, Sloboda DM, Saffery R, Joo E, Vickers MH. Maternal nutritional history modulates the hepatic IGF-IGFBP axis in adult male rat offspring. Endocrine. 2014;46:70-82.

62. Cordero P, Gonzalez-Muniesa P, Milagro Fl, Campion J, Martinez JA. Perinatal maternal feeding with an energy dense diet and/or micronutrient mixture drives offspring fat distribution depending on the sex and growth stage. J Anim Physiol Anim Nutr (Berl). 2015;99:834-40.

63. da Silva Cunha F, Molle RD, Portella AK, da Silva BC, Noschang C, Goldani $M Z$, et al. Both food restriction and high-fat diet during gestation induce low birth weight and altered physical activity in adult rat offspring: the "similarities in the inequalities" model. PLoS One. 2015;10:e0118586.

64. Segovia SA, Vickers MH, Zhang XD, Gray C, Reynolds CM. Maternal supplementation with conjugated linoleic acid in the setting of dietinduced obesity normalises the inflammatory phenotype in mothers and reverses metabolic dysfunction and impaired insulin sensitivity in offspring. J Nutr Biochem. 2015;26:1448-57.

65. Bayol SA, Farrington SJ, Stickland NC. A maternal "junk food" diet in pregnancy and lactation promotes an exacerbated taste for "junk food" and a greater propensity for obesity in rat offspring. Br J Nutr. 2007;98:843-51.

66. Zhang Z-Y, Zeng J-J, Kjaergaard M, Guan N, Raun K, Nilsson C, et al. Effects of a maternal diet supplemented with chocolate and fructose beverage during gestation and lactation on rat dams and their offspring. Clin Exp Pharmacol Physiol. 2011;38:613-22.

67. Gugusheff JR, Ong ZY, Muhlhausler BS. A maternal "junk-food" diet reduces sensitivity to the opioid antagonist naloxone in offspring postweaning. FASEB J. 2013:27:1275-84.

68. Martin JC, Martin DC, Shores P, Chao S. Growth and activity but not maturation are affected by perinatal diet. Physiol Behav. 1987:40:279-85.

69. Cerf ME, Williams K, van Rooyen J, Esterhuyse AJ, Muller CJ, Louw J. Gestational 30 and 40\% fat diets increase brain GLUT2 and neuropeptide $Y$ immunoreactivity in neonatal Wistar rats. Int J Dev Neurosci. 2010;28:625-30.

70. Yang K, Cai W, Xu J, Shi W. Maternal high-fat diet programs Wnt genes through histone modification in the liver of neonatal rats. J Mol Endocrinol. 2012:49:107-14.

71. Tsoulis MW, Chang PE, Moore CJ, Chan KA, Gohir W, Petrik JJ, et al. Maternal high-fat diet-induced loss of fetal oocytes is associated with compromised follicle growth in adult rat offspring. Biol Reprod. 2016;94:94.

72. Ebesh O, Barone A, Harper RG, Wapnir RA. Combined effect of high-fat diet and copper deficiency during gestation on fetal copper status in the rat Biol Trace Elem Res. 1999:67:139-50.

73. Walker C-D, Naef L, d'Asti E, Long H, Xu Z, Moreau A, et al. Perinatal maternal fat intake affects metabolism and hippocampal function in the offspring a potential role for leptin. Neural Signal Oppor Nov Diagn Approaches Ther. 2008;1144:189-202.

74. Lin Y, Han X, Fang Z, Che L, Nelson J, Yan T, et al. Beneficial effects of dietary fibre supplementation of a high-fat diet on fetal development in rats. Br J Nutr. 2011:106:510-8.

75. de Oliveira AF, Fontelles CC, Rosim MP, de Oliveira TF, de Melo Loureiro AP, Mancini-Filho J, et al. Exposure to lard-based high-fat diet during fetal and lactation periods modifies breast cancer susceptibility in adulthood in rats. J Nutr Biochem. 2014:25:613-22

76. Rolls BJ, VanDuijvenvoorde PM, Rowe EA. Effects of diet and obesity on body-weight regulation during pregnancy and lactation in the rat. Physiol Behav. 1984;32:161-8. 
77. Zhang Z-Y, Dai Y-B, Wang H-N, Wang M-W. Supplementation of the maternal diet during pregnancy with chocolate and fructose interacts with the high-fat diet of the young to facilitate the onset of metabolic disorders in rat offspring. Clin Exp Pharmacol Physiol. 2013;40:652-61.

78. Cavalcante TCF, da Silva JML, da Marcelino da Silva AA, Muniz GS, da Luz Neto LM, de Souza SL, et al. Effects of a westernized diet on the reflexes and physical maturation of male rat offspring during the perinatal period. Lipids. 2013;48:1157-68.

79. Cavalcante TCF, da Silva AAM, Lira MCA, do Amaral Almeida LC, Marques APJ, do Nascimento E. Early exposure of dams to a westernized diet has long-term consequences on food intake and physiometabolic homeostasis of the rat offspring. Int J Food Sci Nutr. 2014;65:989-93.

80. Cerf ME, Louw J, Herrera E. High fat diet exposure during fetal life enhances plasma and hepatic Omega-6 fatty acid profiles in fetal Wistar rats. Nutrients. 2015;7:7231-41.

81. Strakovsky RS, Zhang X, Zhou D, Pan Y-X. Gestational high fat diet programs hepatic phosphoenolpyruvate carboxykinase gene expression and histone modification in neonatal offspring rats. J Physiol. 2011;589:2707-17.

82. de Assis S, Khan G, Hilakivi-Clarke L. High birth weight increases mammary tumorigenesis in rats. Int J Cancer. 2006;119:1537-46.

83. Kjaergaard M, Nilsson C, Rosendal A, Nielsen MO, Raun K. Maternal chocolate and sucrose soft drink intake induces hepatic steatosis in rat offspring associated with altered lipid gene expression profile. Acta Physiol. 2014;210:142-53.

84. Mayor RS, Finch KE, Zehr J, Morselli E, Neinast MD, Frank AP, et al. Maternal high-fat diet is associated with impaired fetal lung development. Am J Physiol Cell Mol Physiol. 2015;309:L360-8.

85. Niculescu MD, Lupu DS. High fat diet-induced maternal obesity alters fetal hippocampal development. Int J Dev Neurosci. 2009;27:627-33.

86. Bentham J, Michell AC, Lockstone H, Andrew D, Schneider JE, Brown NA, et al. Maternal high-fat diet interacts with embryonic Cited2 genotype to reduce Pitx2c expression and enhance penetrance of left-right patterning defects. Hum Mol Genet. 2010;19:3394-401.

87. King V, Dakin RS, Liu L, Hadoke PWF, Walker BR, Seckl JR, et al. Maternal obesity has little effect on the immediate offspring but impacts on the next generation. Endocrinology. 2013;154:2514-24.

88. King V, Hibbert N, Seckl JR, Norman JE, Drake AJ. The effects of an obesogenic diet during pregnancy on fetal growth and placental gene expression are gestation dependent. Placenta. 2013;34:1087-90.

89. Sasson IE, Vitins AP, Mainigi MA, Moley KH, Simmons RA. Pre-gestational vs gestational exposure to maternal obesity differentially programs the offspring in mice. Diabetologia. 2015;58:615-24.

90. Edlow AG, Guedj F, Pennings JLA, Sverdlov D, Neri C, Bianchi DW. Males are from Mars, and females are from Venus: sex-specific fetal brain gene expression signatures in a mouse model of maternal diet-induced obesity. Am J Obstet Gynecol. 2016;214:623.e1-623.e10.

91. Panchenko PE, Voisin $S$, Jouin $M$, Jouneau $L$, Prezelin $A$, Lecoutre $S$, et al. Expression of epigenetic machinery genes is sensitive to maternal obesity and weight loss in relation to fetal growth in mice. Clin Epigenetics. 2016;8:22.

92. Lager S, Samulesson A-M, Taylor PD, Poston L, Powell TL, Jansson T. Dietinduced obesity in mice reduces placental efficiency and inhibits placental mTOR signaling. Physiol Rep. 2014;2:e00242.

93. Umekawa T, Sugiyama T, Du Q, Murabayashi N, Zhang L, Kamimoto Y, et al. A maternal mouse diet with moderately high-fat levels does not lead to maternal obesity but causes mesenteric adipose tissue dysfunction in male offspring. J Nutr Biochem. 2015;26:259-66.

94. Liang C, Oest ME, Jones JC, Prater MR. Gestational high saturated fat diet alters C57BL/6 mouse perinatal skeletal formation. Birth Defects Res B Dev Reprod Toxicol. 2009;86:362-9.

95. Bytautiene E, Tamayo E, Kechichian T, Drever N, Gamble P, Hankins GDV, et al. Prepregnancy obesity and sFlt1-induced preeclampsia in mice: developmental programming model of metabolic syndrome. Am J Obstet Gynecol. 2011;204:398.e1-8.

96. Murabayashi N, Sugiyama T, Zhang L, Kamimoto $Y$, Umekawa T, Ma N, et al. Maternal high-fat diets cause insulin resistance through inflammatory changes in fetal adipose tissue. Eur J Obstet Gynecol Reprod Biol. 2013;169:39-44

97. Aye $I L M H$, Rosario FJ, Powell $\mathrm{TL}$, Jansson T. Adiponectin supplementation in pregnant mice prevents the adverse effects of maternal obesity on placental function and fetal growth. Proc Nat Acad Sci U S A. 2015;112:12858-63.
98. Rosario FJ, Kanai Y, Powell TL, Jansson T. Increased placental nutrient transport in a novel mouse model of maternal obesity with fetal overgrowth. Obesity. 2015;23:1663-70.

99. Masuyama $\mathrm{H}$, Hiramatsu $\mathrm{Y}$. Effects of a high-fat diet exposure in utero on the metabolic syndrome-like phenomenon in mouse offspring through epigenetic changes in Adipocytokine gene expression. Endocrinology. 2012;153:2823-30.

100. Masuyama H, Hiramatsu Y. Treatment with a constitutive androstane receptor ligand ameliorates the signs of preeclampsia in high-fat dietinduced obese pregnant mice. Mol Cell Endocrinol. 2012;348:120-7.

101. Dahlhoff M, Pfister S, Blutke A, Rozman J, Klingenspor M, Deutsch MJ, et al. Peri-conceptional obesogenic exposure induces sex-specific programming of disease susceptibilities in adult mouse offspring. Biochim Biophys Acta. 1842;2014:304-17.

102. Masuyama $\mathrm{H}$, Hiramatsu Y. Additive effects of maternal high fat diet during lactation on mouse offspring. PLoS One. 2014;9:e92805.

103. Masuyama H, Mitsui T, Nobumoto E, Hiramatsu Y. The effects of high-fat diet exposure in utero on the obesogenic and Diabetogenic traits through epigenetic changes in adiponectin and leptin gene expression for multiple generations in female mice. Endocrinology. 2015;156:2482-91.

104. Sferruzzi-Perri AN, Vaughan OR, Haro M, Cooper WN, Musial B, Charalambous $\mathrm{M}$, et al. An obesogenic diet during mouse pregnancy modifies maternal nutrient partitioning and the fetal growth trajectory. FASEB J. 2013;27:3928-37.

105. Turdi S, Ge W, Hu N, Bradley KM, Wang X, Ren J. Interaction between maternal and postnatal high fat diet leads to a greater risk of myocardial dysfunction in offspring via enhanced lipotoxicity, IRS-1 serine phosphorylation and mitochondrial defects. J Mol Cell Cardiol. 2013;55:117-29.

106. del Mar PM, Williams L, Seki Y, Hartil K, Kaur H, Lin C-L, et al. Critical periods of increased fetal vulnerability to a maternal high fat diet. Reprod Biol Endocrinol. 2014;12:80.

107. Luijten $M$, Singh AV, Bastian CA, Westerman A, Pisano MM, Pennings JLA, et al. Lasting effects on body weight and mammary gland gene expression in female mice upon early life exposure to $n-3$ but not $n-6$ high-fat diets. PLoS One. 2013;8:e55603.

108. Benatti RO, Melo AM, Borges FO, Ignacio-Souza LM, Simino LAP, Milanski M, et al. Maternal high-fat diet consumption modulates hepatic lipid metabolism and microRNA-122 (miR-122) and microRNA-370 (miR-370) expression in offspring. Br J Nutr. 2014;111:2112-22.

109. Volpato AM, Schultz A, Magalhaes-da-Costa E, de Gusmao Correia ML, Aguila MB, Mandarim-de-Lacerda CA. Maternal high-fat diet programs for metabolic disturbances in offspring despite leptin sensitivity. Neuroendocrinology. 2012;96:272-84.

110. Ashino NG, Saito KN, Souza FD, Nakutz FS, Roman EA, Velloso LA, et al. Maternal high-fat feeding through pregnancy and lactation predisposes mouse offspring to molecular insulin resistance and fatty liver. J Nutr Biochem. 2012;23:341-8 Elsevier Inc.

111. Gregorio BM, Souza-Mello V, Mandarim-de-Lacerda CA, Aguila MB. Maternal high-fat diet is associated with altered pancreatic remodelling in mice offspring. Eur J Nutr. 2013;52:759-69.

112. Chin EH, Christians JK. When are sex-specific effects really sex-specific? J Dev Orig Health Dis. 2015;6:438-42.

113. Dodson RB, Miller TA, Powers $K$, Yang Y, Yu B, Albertine $K H$, et al. Intrauterine growth restriction influences vascular remodeling and stiffening in the weanling rat more than sex or diet. Am J Physiol Heart Circ Physiol. 2017;312:H250-64.

114. Huang Y, Ye T, Liu C, Fang F, Chen Y, Dong Y. Maternal high-fat diet during pregnancy and lactation affects hepatic lipid metabolism in early life of offspring rat. J Biosci. 2017:42:311-9.

115. Ye K, Li L, Zhang D, Li Y, Wang HQ, Lai HL, et al. Effect of maternal obesity on fetal growth and expression of placental fatty acid transporters. J Clin Res Pediatr Endocrinol. 2017;9:300-7.

116. Yamada-Obara N, Yamagishi S, Taguchi K, Kaida Y, Yokoro M, Nakayama Y, et al. Maternal exposure to high-fat and high-fructose diet evokes hypoadiponectinemia and kidney injury in rat offspring. Clin Exp Nephrol. 2016;20:853-61.

117. Lecoutre S, Deracinois B, Laborie C, Eberlé D, Guinez C, Panchenko PE, et al. Depot- and sex-specific effects of maternal obesity in offspring's adipose tissue. J Endocrinol. 2016;230:39-53.

118. Bae-Gartz I, Janoschek R, Kloppe CS, Vohlen C, Roels F, Oberthür A, et al. Running exercise in obese pregnancies prevents IL-6 trans-signaling in male offspring. Med Sci Sports Exerc. 2016;48:829-38. 
119. Chin EH, Schmidt KL, Martel KM, Wong CK, Hamden JE, Gibson WT, et al. A maternal high-fat, high-sucrose diet has sex-specific effects on fetal glucocorticoids with little consequence for offspring metabolism and voluntary locomotor activity in mice. PLoS One. 2017;12:e0174030.

120. Jonscher KR, Stewart MS, Alfonso-Garcia A, DeFelice BC, Wang XX, Luo Y, et al. Early PQQ supplementation has persistent long-term protective effects on developmental programming of hepatic lipotoxicity and inflammation in obese mice. FASEB J. 2017;31:1434-48.

121. Connor KL, Chehoud C, Altrichter A, Chan L, DeSantis TZ, Lye SJ. Maternal metabolic, immune, and microbial systems in late pregnancy vary with malnutrition in mice. Biol Reprod. 2018;98:579-92.

122. Masuyama H, Mitsui T, Maki J, Tani K, Nakamura K, Hiramatsu Y. Dimethylesculetin ameliorates maternal glucose intolerance and fetal overgrowth in high-fat diet-fed pregnant mice via constitutive androstane receptor. Mol Cell Biochem. 2016;419:185-92.

123. Nam J, Greenwald E, Jack-Roberts C, Ajeeb TT, Malysheva OV, Caudill MA, et al. Choline prevents fetal overgrowth and normalizes placental fatty acid and glucose metabolism in a mouse model of maternal obesity. J Nutr Biochem. 2017:49:80-8

124. Lai M, Chandrasekera PC, Barnard ND. You are what you eat, or are you? The challenges of translating high-fat-fed rodents to human obesity and diabetes. Nutr Diabetes. 2014;4:e135.

125. Pellizzon MA, Ricci MR. The common use of improper control diets in dietinduced metabolic disease research confounds data interpretation: The fiber factor. Nutr Metab. 2018;15:3.

126. Austin GL, Ogden LG, Hill JO. Trends in carbohydrate, fat, and protein intakes and association with energy intake in normal-weight, overweight, and obese individuals: 1971-2006. Am J Clin Nutr. 2011;93:836-43.

127. Ford ES, Dietz WH. Trends in energy intake among adults in the United States: findings from NHANES. Am J Clin Nutr. 2013;97:848-53.

128. Wright JD, Wang C, Kennedy-Stephenson J, Ervin RB. Dietary intake of ten key nutrients for public health, United States: 1999-2000. Adv Data. 2003;334:1-4.

129. Frihauf JB, Fekete ÉM, Nagy TR, Levin BE, Zorrilla EP. Maternal Western diet increases adiposity even in male offspring of obesity-resistant rat dams: early endocrine risk markers. Am J Physiol Regul Integr Comp Physiol. 2016;311:R1045-59.

130. Shankar K, Harrell A, Liu X, Gilchrist JM, Ronis MJJ, Badger TM. Maternal obesity at conception programs obesity in the offspring. Am J Physiol Regul Integr Comp Physiol. 2008;294:R528-38.

131. Lin Y, Zhuo Y, Fang Z, Che L, Wu D. Effect of maternal dietary energy types on placenta nutrient transporter gene expressions and intrauterine fetal growth in rats. Nutrition. 2012;28:1037-43.

132. Fornes R, Maliqueo M, Hu M, Hadi L, Jimenez-Andrade JM, Ebefors K, et al. The effect of androgen excess on maternal metabolism, placental function and fetal growth in obese dams. Sci Rep. 2017;7:8066.

133. Djelantik AAAMJ, Kunst AE, Van Der Wal MF, Smit HA, Vrijkotte TGM. Contribution of overweight and obesity to the occurrence of adverse pregnancy outcomes in a multi-ethnic cohort: population attributive fractions for Amsterdam. BJOG An Int J Obstet Gynaecol. 2012;119:283-90.

134. Li N, Liu E, Guo J, Pan L, Li B, Wang P, et al. Maternal prepregnancy body mass index and gestational weight gain on pregnancy outcomes. PLoS One. 2013;8:e82310.

135. Scott-Pillai R, Spence D, Cardwell CR, Hunter A, Holmes VA. The impact of body mass index on maternal and neonatal outcomes: a retrospective study in a UK obstetric population, 2004-2011. Br J Obstet Gynaecol. 2013;120:932-9.

136. Sebire NJ, Jolly M, Harris JP, Wadsworth J, Joffe M, Beard RW, et al. Maternal obesity and pregnancy outcome: a study of 287213 pregnancies in London. Int J Obes. 2001:25:1175-82.

137. Jeyabalan A. Epidemiology of preeclampsia: impact of obesity. Nutr Rev. 2013.71:S18-25

138. Villar J, Carroli G, Wojdyla D, Abalos E, Giordano D, Ba'aqeel H, et al. Preeclampsia, gestational hypertension and intrauterine growth restriction, related or independent conditions? Am J Obstet Gynecol. 2006;194:921-31.

139. Weiss JL, Malone FD, Emig D, Ball RH, Nyberg DA, Comstock CH, et al. Obesity, obstetric complications and cesarean delivery rate - a populationbased screening study. Am J Obstet Gynecol. 2004;190:1091-7.

140. Cedergren MI. Maternal morbid obesity and the risk of adverse pregnancy outcome Obstet Gynecol. 2004:103:219-24.
141. Reynolds RM, Allan KM, Raja EA, Bhattacharya S, McNeill G, Hannaford PC, et al. Maternal obesity during pregnancy and premature mortality from cardiovascular events in adult offspring: follow-up of 1,323,275 person years. BMJ. 2013;347:f4539.

142. Dickinson H, Moss TJ, Gatford KL, Moritz KM, Akison L, Fullston T, et al. A review of fundamental principles for animal models of $\mathrm{DOHaD}$ research: an Australian perspective. J Dev Orig Health Dis. 2016;7:449-72.

143. Williams L, Seki Y, Vuguin PM, Charron MJ. Animal models of in utero exposure to a high fat diet: a review. Biochim Biophys Acta-Molecular Basis Dis. 1842;2014:507-19.

144. Montgomery MK, Hallahan NL, Brown SH, Liu M, Mitchell TW, Cooney GJ, et al. Mouse strain-dependent variation in obesity and glucose homeostasis in response to high-fat feeding. Diabetologia. 2013;56:1129-39.

145. Simon MM, Greenaway S, White JK, Fuchs H, Gailus-Durner V, Wells S, et al. A comparative phenotypic and genomic analysis of C57BL/6J and C57BL/6N mouse strains. Genome Biol. 2013;14:R82.

146. Morrison JL, Botting KJ, Darby JRT, David AL, Dyson RM, Gatford KL, et al. Guinea pig models for translation of the developmental origins of health and disease hypothesis into the clinic. J Physiol. 2018;596:5535-69.

147. Chavatte-Palmer P, Tarrade A, Rousseau-Ralliard D. Diet before and during pregnancy and offspring health: the importance of animal models and what can be learned from them. Int J Environ Res Public Health. 2016;13:586.
Ready to submit your research? Choose BMC and benefit from:

- fast, convenient online submission

- thorough peer review by experienced researchers in your field

- rapid publication on acceptance

- support for research data, including large and complex data types

- gold Open Access which fosters wider collaboration and increased citations

- maximum visibility for your research: over $100 \mathrm{M}$ website views per year

At BMC, research is always in progress.

Learn more biomedcentral.com/submissions 